\title{
Vegetation Response to Contour
}

\section{Furrowing}

\author{
J. ROSS WIGHT, E. L. NEFF, AND R. J. SOISETH
}

Highlight: Over an 8-year period, contour furrowing on a panspot range site increased average annual herbage production $165 \%(527 \mathrm{~kg} / \mathrm{ha})$, increased plant available soil water $107 \%$, and reduced total basal cover $73 \%$ (from 15.72 to $4.22 \%$ ). On a saline-upland site, contour furrowing increased available water but had no measurable effect on total herbage production and basal cover. Thickspike and western wheatgrass accounted for most of the increased yields on the contourfurrowed panspot site. High yields on the furrowed plots were due primarily to increased soil water resulting from increased overwinter recharge and reduced summer runoff.

Range forage production in arid and semiarid regions is closely associated with soil water availability, which is limited by precipitation amounts and runoff. Contour furrowing was one of the first land surface modification treatments applied to rangeland to reduce nunoff. Since this treatment was introduced in the 1930's, it has been applied in a wide variety of furrow sizes and spacings. While optimum spacing is related to furrow size, spacings wider than 1.5 to $1.8 \mathrm{~m}$ have generally been ineffective (Bennett 1939; Barnes 1950). In the past 20 years, most contour furrowing has been done with the Arcadia Model B contour furrower developed by the U.S. Forest Service. Herbage yield responses to contour furrowing have ranged from none to increases of $100 \%$ or more and have been closely associated with the type of furrowing treatment and site characteristics (Wight 1976). In addition to increasing forage production, contour furrowing has been used extensively, primarily by the Bureau of Land Management, to reduce runoff and crosion on fine-textured, erodible rangelands.

Authors are range scientist, research hydraulic engineer, and agricultural research technician. respectively, U.S. Department of Agriculture, Agricultural Research Service. Northern Plains Soil and Water Research Center, Sidney, Montana 59270. R. J. Soiseth is now supervisory range conservationist, U.S. Department of the Interior, Bureau of Land Management, P.O. Box B, Malta, Mont. 59538

This report is a contribution from the U.S. Dep Agr Agr. Res. Serv., in cooperation ith the Mont. Agr. Exp. Sta. Journal Series No. 755

Manuscript received June 16, 1977
At present, contour furrowing is generally not used as a range improvement practice because unfavorable economics have discouraged its use by private landowners, and changes in management philosophies have restricted its use by the Bureau of Land Management and other land management agencies. However, on rangelands with high runoff and resultant low productivity, contour furrowing can significantly reduce runoff and increase forage production. More information is needed regarding long-term vegetation responses and site-treatment interactions. The purpose of this paper is to examine the vegetation responses of panspot and saline-upland range sites to contour furrowing. Vegetation responses were examined in terms of herbage production, species composition, and associated environmental factors. The results and data presented here are part of a cooperative study between the Agricultural Research Service, U.S. Department of Agriculture, and the Bureau of Land Management, U.S. Department of the Interior, to evaluate contour furrowing effects on the vegetation and hydrology of fine-textured rangelands in southeastern Montana.

\section{Site Description and Methods}

This study was conducted about $29 \mathrm{~km}$ south of Ekalaka in the southeast corner of Montana. The climate is arid to semiarid continental with cold, relatively dry winters and warm summers. The long-time average annual precipitation is about $300 \mathrm{~mm}$, with
$80 \%$ of the precipitation received during April through September. Based on data from nearby weather stations, the precipitation during 1968-76 study was about $120 \%$ of the 76-year average and about $115 \%$ of the last 22 -year average. The average frostfree season is 127 days.

The contour furrowing treatments were applied to panspot and saline-upland range sites, which are characterized by impervious saline-sodic soils with low forage productivity. The panspot soils are in the Bickerdyne and Bascovy series, fine or very fine, montmorillonitic, Borollic Vertic Camborthids. The saline-upland soils are in the Dilts series, clayey, montmorillonitic, acid, frigid, shallow Ustic Torriorthents. A dominant feature of these soils is low infiltration and high runoff. Neff and Wight (1977) estimated that approximately $40 \%$ of the late fall, winter, and early spring precipitation was lost by runoff.

Vegetation of the panspot site included thickspike wheatgrass (Agropyron dasystachyum), western wheatgrass (A. smithii), Sandberg bluegrass (Poa secunda), prairie Junegrass (Koeleria crista(a), big sagebrush (Artemisia tridentata), and pricklypear cactus (Opuntia sp.). Small residual pedestals of coarse-textured materials had abundant blue grama (Bouteloua gracilis), buffalograss (Buchloe dactyloides), and clubmoss (Selaginella densa). The saline-upland site was dominated by alkali sacaton (Sporobolus airoides) and Nuttall alkaligrass (Puccinellia airoides). Other species present were Nuttall saltbush (Atriplex nuttallii), broom snakeweed (Gutierrezia sarothrae), racemed poisonvetch (Astragalus racemosus), and Eriogonum multiceps.

Sixteen 0.8-hectare watersheds, twelve on the panspot range site with average slopes of 1 to $5 \%$ and four on the salineupland range site with an average slope of $3 \%$, were established in November 1967. Half of the watersheds at each site were contour furrowed with the Arcadia Model B contour furrower. Two pairs of offset disks $1.5 \mathrm{~m}$ apart formed two furrows approximately $50 \mathrm{~cm}$ wide and 15 to $25 \mathrm{~cm}$ deep. Rippers ahead of the disks fractured the soil to a depth of 25 to $40 \mathrm{~cm}$. Intrafurrow dams were constructed about every $5 \mathrm{~m}$. The furrow and the ridge portions represented 
about 40 to $60 \%$, respectively, of the treated area. The treatments were applied in a randomized complete block design with treatments replicated six times on the panspot site and two times on the salineupland site.

Annual herbage production was determined by clipping vegetation at ground level in eight randomly located $0.25-x$ 2 -m quadrats or four $0.5-\times 2$-m quadrats in each watershed. Plots were clipped when vegetation reached peak standing crop, usually in late July or early August. No yield measurements were made in 1973 because of early grazing. Yields were determined separately for the dominant species and major species groups (i.e., grasses, forbs, and shrubs). Because of the difficulty in separating thickspike and western wheatgrass, the thickspike-western wheatgrass complex was harvested as a single category. No estimates were made of annual big sagebrush growth. Furrows and ridges were harvested separately in 1968 , $1969,1970,1972$, and 1976; in the other years, sampling quadrats were located to include a proportional amount of ridge and furrow. There was no measurable productivity in the furrows until 1971. Grazing was not a treatment but plots were grazed in 1969,1971 , and 1973 to remove accumulated residue.

Soil water was measured by the neutron scatter method to a depth of $120 \mathrm{~cm}$ periodically (biwcekly to monthly) during the growing seasons at two locations in each watershed and included both ridges and furrows of the treated plots. Cm-days of available water was determined by plotting soil water content for the April 1 to July 31 growing season and measuring the area between the plot and a base line representing the water content below which water was unavailable to plants. This integrated area is an index reflecting both the amount and duration of available soil water. The base line or lower limit of soil water availability was determined as the lowest water content that occurred naturally in the field during the 9-year study. Because most of the root activity on these two sites is limited to the top $60 \mathrm{~cm}$ of soil profile, available soil water was determined for this zone only.

Nitrogen (N) and phosphorus (P) contents were determined annually on the mature thickspike-western wheatgrass plants.

Basal cover was determined for the years 1968-71 and again in 1974 with the point quadrat method. Species composition based on basal cover was determined in 1974. Point data were taken along six permanently located line transects at $5-\mathrm{cm}$ intervals with a 20 -point frame for a total of 1,200 points per plot. Only the basal hits are discussed in this paper. The percentage basal cover data were normalized by the transformation

$$
X=\sqrt{X+0.5}
$$

Table 1. Average annual herbage yields ( $\mathrm{kg} / \mathrm{ha}$ ) and composition on check and furrowed plots for 1969-1976.

\begin{tabular}{|c|c|c|c|c|c|c|}
\hline \multirow[b]{3}{*}{ Species } & \multicolumn{6}{|c|}{ Site } \\
\hline & \multicolumn{3}{|c|}{ Saline-upland } & \multicolumn{3}{|c|}{ Panspot } \\
\hline & Check & Furrowed & $\begin{array}{c}\text { Furrowed/ } \\
\text { check }\end{array}$ & Check & Furrowed & $\begin{array}{c}\text { Furrowed/ } \\
\text { check** }\end{array}$ \\
\hline Nuttall alkaligrass & 23 & 80 & 3.47 & - & - & - \\
\hline Alkali sacaton & 59 & 73 & 1.26 & - & - & - \\
\hline Thickspike-western wheatgrass & 23 & 29 & 1.22 & 119 & $558^{*}$ & 4.64 \\
\hline Total grass & 139 & 218 & 1.55 & 271 & $704^{*}$ & 2.60 \\
\hline Forbs & 78 & 114 & 1.49 & 31 & $129 *$ & 4.00 \\
\hline Total & 241 & 350 & 1.45 & 320 & $847^{*}$ & 2.65 \\
\hline Percent grass & 58 & 62 & - & 85 & 83 & - \\
\hline
\end{tabular}

* Means significantly different from the check $(P=0.1)$.

**Furrowed/check data not analyzed statistically.

and analyzed statistically. All data were analyzed with a split-plot analysis of variance with furrowing treatments as the main plots and years as the subplots.

\section{Results and Discussion}

\section{Herbage Production}

The effect of contour furrowing on herbage production is shown in Table 1 and Figure 1. Except for the treatment year, contour furrowing generally incrcascd herbage production on all plots. On the saline-upland site, yield increases due to contour furrowing were not significant $(P=0.1)$. However, with only two replications and two treatments, an analysis of variance was not very discerning. On the panspot site, furrowing increased average herbage production $527 \mathrm{~kg} / \mathrm{ha}(165 \%)$.

Increases in the dominant forage species accounted for most of the yield increases on the contour-furrowed plots. Nuttall alkaligrass and alkali sacaton increased 247 and $26 \%$, respectively, on the saline-upland site; and thickspike-western wheatgrass increased $364 \%$ on the panspot sites (Table 1). Blue grama and buffalo- grass, which represented about $25 \%$ of the basal cover on the nonfurrowed panspot site, accounted for only 17.8 and $1.7 \%$ of the total production on the check and furrowed plot, respectively. Forbs, which accounted for only 10 and $32 \%$ of the total production on the untreated panspot and saline-upland sites, respectively, responded to contour furrowing in about the same proportion as did the dominant grasses. The major forb response to contour furrowing on the panspot site in 1976 was a heavy infestation of yellow sweetclover (Melilotus officinalis).

\section{$\mathbf{N}$ and $P$ Uptake}

Herbage quality as determined by $N$ and $P$ contents of thickspike-western wheatgrass was significantly affected by contour furrowing (Fig. 2). In 1968 , both the $N$ and $P$ contents were higher on furrowed than on nonfurrowed plots, indicating a nutrient enrichment as disturbed soil and sod weathered and decomposed. However, during the next few years, $N$ and $P$ contents were generally lower in the furrowed than in the nonfurrowed plots, indicating a

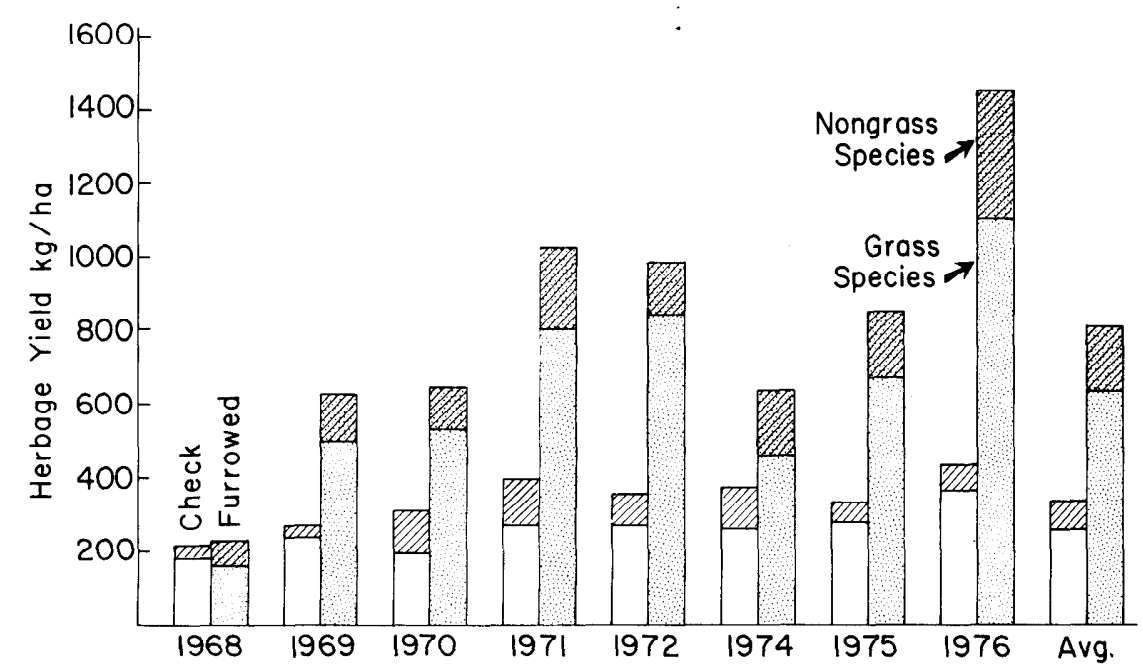

Fig. 1. Herbage production under contour furrowing on panspot range site. 


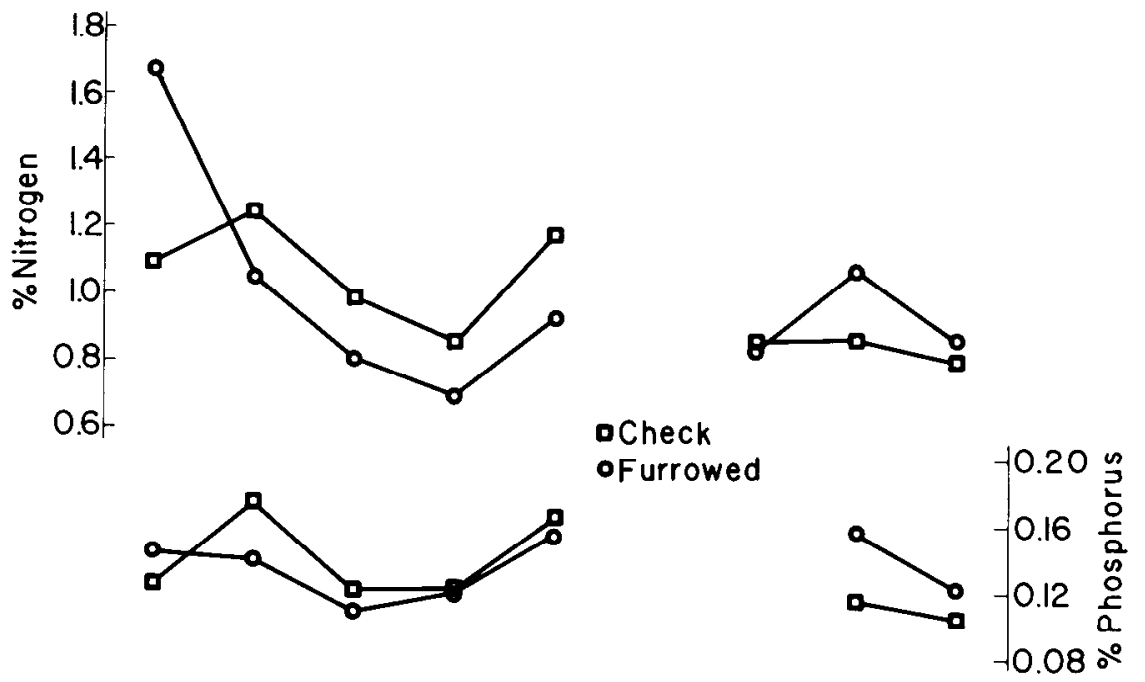

$\begin{array}{llllllll}1968 & 1 & 1 & 1 & 1 & 1 & 1 & 1 \\ 70 & 71 & 72 & 73 & 74 & 75 & 1976\end{array}$

Fig. 2. $N$ and $P$ content of thickspike western wheatgrass under contour furrowing.

dilution effect as the furrowed plots produced 2 to 3 times more vegetation than did the nonfurrowed plots. Also, decreases in $\mathrm{N}$ and $\mathrm{P}$ contents are associated with decreases in leaf:stem ratios as plants grow more vigorously. Although $\mathrm{N}$ and $\mathrm{P}$ contents were lower on the furrowed than on the nonfurrowed plots, total uptake of $\mathrm{N}$ and $\mathrm{P}$ was higher on the furrowed plots because of the increased production. As indicated in Figure 2, this situation again reversed itself in about 7 years, with the furrowed plots producing forage higher in $\mathrm{N}$ and $\mathrm{P}$ contents than did the nonfurrowed plots. After 7 years of increased soil water and productivity on the furrowed plots, the soil nutricnts were probably cycling in greater quantities on the furrowed than on the nonfurrowed plots.

Table 2. A comparison of herbage production rates $(\mathrm{kg} / \mathrm{ha})$ in the furrows $(F)$, ridges $(R)$, and checks $(\mathrm{C})$.

\begin{tabular}{|c|c|c|c|c|c|c|c|c|c|c|}
\hline \multirow[b]{2}{*}{ Species } & \multicolumn{3}{|c|}{1969} & \multicolumn{3}{|c|}{1972} & \multicolumn{3}{|c|}{1976} & \multirow[b]{2}{*}{ LSD } \\
\hline & $\mathbf{F}$ & $\mathbf{R}$ & $\mathrm{C}$ & $\mathrm{F}$ & $\mathbf{R}$ & $\mathrm{C}$ & $\mathrm{F}$ & $\mathbf{R}$ & C & \\
\hline \multicolumn{11}{|l|}{ Saline-upland } \\
\hline Nuttall alkaligrass & 0 & 76 & 6 & 56 & 97 & 9 & 110 & 82 & 46 & 180 \\
\hline Alkali sacaton & 0 & 2 & 66 & 0 & 87 & 40 & 79 & 211 & 100 & 121 \\
\hline Forbs & 0 & 193 & 49 & 87 & 186 & 49 & 86 & 131 & 233 & 205 \\
\hline Total grass & 0 & 155 & 102 & 182 & 355 & 123 & 188 & 292 & 178 & 97 \\
\hline Total yield & 0 & 350 & 159 & 287 & 541 & 206 & 302 & 432 & 467 & 236 \\
\hline \multicolumn{11}{|l|}{ Panspot } \\
\hline $\begin{array}{c}\text { Thickspike-western } \\
\text { wheatgrass }\end{array}$ & 0 & 619 & 121 & 406 & 880 & 95 & 423 & 900 & 115 & 205 \\
\hline Foxtail & 0 & 12 & 0 & - & - & - & 137 & 22 & 0 & - \\
\hline Forbs & 0 & 188 & 22 & 97 & 55 & 27 & 388 & 312 & 31 & 185 \\
\hline Shrubs & 0 & 28 & 10 & 3 & 10 & 17 & 0 & 9 & 40 & 32 \\
\hline Total grass & 0 & 835 & 242 & 614 & 984 & 273 & 722 & 1364 & 365 & 207 \\
\hline Total yield & 0 & 1051 & 274 & 714 & 1049 & 317 & 1111 & 1685 & 436 & 244 \\
\hline
\end{tabular}

$\operatorname{LSD}(P=0.1)$ valid for within-year comparisons only. wheatgrass accounted for most of the herbage production in the panspot furrows. On the saline-upland site, Nuttall alkaligrass was more productive in the furrows than on the ridges or check plots while alkali sacaton favored the ridges and the check plots more than the furrows.

Changes in percent composition 7 years after treatment are shown in Table 3. Most changes were beneficial, with the biggest changes occurring in the major forage species-Nuttall alkaligrass, alkali sacaton, and the thickspike-western wheatgrass. Tumblegrass and foxtail barley (Hordeum jubatum), which are of little forage value, also increased in the furrows of the panspot site. Foxtail barley was restricted almost entirely to those furrowed areas where water remained ponded for a considerable time. However, in 1976 tumblegrass and foxtail barley comprised only 2.0 and $1.2 \%$, respectively, of the total grass yield.

\section{Basal Cover}

On the saline-upland site, only the basal cover of alkali sacaton and the shrubs was initially reduced by contour furrowing (Table 3 ). However, by 1974 , there were no measurable differences in the check and contourfurrowed plots. On the panspot site, contour furrowing reduced the basal cover of nearly all species except thickspike-western wheatgrass and tumblegrass; these were increased. Contour furrowing reduced total basal cover from 15.72 to $4.28 \%$, mostly due to a reduction in clubmoss from 9.38 to $0.36 \%$. Disregarding clubmoss, the basal cover 7 years after treatment on the furrowed plots was still only about half that on the nonfurrowed plots (3.86 vs $6.35 \%$ ). Blue grama and buffalograss were also significantly reduced by contour furrowing and accounted for much of the loss in total cover on the furrowed plots. Except for the first year after treatment on the saline-upland site, there were no measurable changes in shrub cover as a result of contour furrowing.

\section{Soil Water}

Increased soil water was the major beneficial effect of the contour furrowing treatments and was closely associated with changes in herbage production. In a previous paper, Neff and Wight (1977) reported that contour furrowing increased overwinter recharge 157 and $162 \%$, respectively, on the saline-upland and panspot sites and 
Table 3. Basal cover and composition of species and species groups on check and furrowed plots.

\begin{tabular}{|c|c|c|c|c|c|c|c|c|c|c|c|c|}
\hline \multirow[b]{3}{*}{ Species } & \multicolumn{10}{|c|}{ Basal cover \% } & \multirow{2}{*}{\multicolumn{2}{|c|}{$\begin{array}{c}\text { Composition \% } \\
1974 \\
\end{array}$}} \\
\hline & \multicolumn{2}{|c|}{1968} & \multicolumn{2}{|c|}{1969} & \multicolumn{2}{|c|}{1970} & \multicolumn{2}{|c|}{1971} & \multicolumn{2}{|c|}{1974} & & \\
\hline & $\mathrm{C}^{1}$ & $\mathrm{~F}^{2}$ & $\mathrm{C}$ & $\mathrm{F}$ & $\mathrm{C}$ & $\mathrm{F}$ & $\mathrm{C}$ & $\mathrm{F}$ & $\mathrm{C}$ & $\mathbf{F}$ & $\mathrm{C}$ & $\mathrm{F}$ \\
\hline \multicolumn{13}{|l|}{ Saline-upland } \\
\hline Thickspike-western wheatgrass & 0.21 & 0.04 & 0.29 & 0.21 & 0.13 & 0.21 & 0.17 & 0.29 & 0.13 & 0.29 & 6.5 & 18.6 \\
\hline Nutall alkaligrass & 0.17 & 0.21 & 0.25 & 0.25 & 0.04 & 0.17 & 0.08 & 0.29 & 0.08 & 0.21 & 4.4 & 13.8 \\
\hline Alkali sacaton & 1.50 & $0.33 *$ & 0.71 & 0.17 & 0.83 & $0.21 *$ & 1.00 & $0.42 *$ & 0.71 & 0.50 & 52.0 & 32.4 \\
\hline Total grass & 1.88 & $0.58^{*}$ & 1.29 & $0.75^{*}$ & 1.08 & $0.67 *$ & 1.29 & 1.08 & 1.08 & 1.17 & 74.9 & 77.1 \\
\hline Total forb & 1.04 & 0.21 & 0.38 & 0.42 & 0.46 & 0.21 & 0.33 & 0.25 & 0.29 & 0.29 & 18.6 & 19.5 \\
\hline Total shrub & 0.54 & $0.25^{*}$ & 0.21 & 0.04 & 0.04 & 0.00 & 0.00 & 0.00 & 0.13 & 0.04 & 6.5 & 3.3 \\
\hline Total cover & 3.46 & $1.04 *$ & 1.88 & 1.21 & 1.58 & 0.88 & 1.63 & 1.33 & 1.50 & 1.50 & & \\
\hline \multicolumn{13}{|l|}{ Panspot } \\
\hline Thickspike-western wheatgrass & 0.67 & 0.43 & 0.85 & 1.10 & 0.75 & $1.69 *$ & 0.63 & $2.40^{*}$ & 0.71 & $1.39 *$ & 5.4 & $35.5^{*}$ \\
\hline Blue grama & 1.92 & $0.29 *$ & 1.64 & 0.32 & 2.46 & 0.60 & 1.58 & 0.35 & 1.82 & 0.61 & 15.8 & 14.6 \\
\hline Buffalograss & 0.83 & $0.25^{*}$ & 0.97 & $0.26 *$ & 1.47 & $0.32 *$ & 0.88 & 0.42 & 1.29 & $0.17 *$ & 9.3 & 4.8 \\
\hline Sandberg bluegrass & 0.58 & 0.18 & 0.53 & 0.47 & 0.81 & $0.26^{*}$ & 1.06 & $0.47 *$ & 1.08 & $0.57 *$ & 7.7 & 10.7 \\
\hline Tumblegrass & 0.06 & 0.13 & 0.00 & $0.17 *$ & 0.00 & $0.13 *$ & 0.03 & $0.17^{*}$ & 0.04 & 0.26 & 0.2 & 6.2 \\
\hline Foxtail barley & 0.00 & 0.00 & 0.00 & 0.00 & 0.00 & 0.00 & 0.00 & 0.08 & 0.00 & 0.42 & 0.0 & 1.2 \\
\hline Cactus & 0.83 & $0.06^{*}$ & 0.65 & $0.07 *$ & 0.42 & $0.07 *$ & 0.57 & $0.07 *$ & 0.24 & 0.08 & 1.8 & 1.8 \\
\hline Clubmoss & 9.03 & $0.19^{*}$ & 10.13 & $0.31 *$ & 8.38 & $0.11^{*}$ & 8.75 & $0.26^{*}$ & 9.38 & $0.36^{*}$ & 47.9 & $7.0^{*}$ \\
\hline Big sage & 0.81 & $0.42 *$ & 0.74 & 0.60 & 0.53 & 0.47 & 0.57 & 0.36 & 0.32 & 0.21 & 2.2 & 4.6 \\
\hline Total grass & 5.33 & $1.38^{*}$ & 4.67 & $2.54 *$ & 5.92 & $3.10^{*}$ & 4.53 & $4.13^{*}$ & 5.63 & $3.24 *$ & 46.2 & $77.1^{*}$ \\
\hline Total forb & 10.92 & $0.50 *$ & 11.15 & $0.85 *$ & 9.10 & 0.54 & 9.50 & 0.69 & 9.74 & 0.71 & 51.0 & 16.4 \\
\hline Total shrub & 0.85 & 0.65 & 0.82 & 0.78 & 0.64 & 0.57 & 0.61 & 0.46 & 0.36 & 0.28 & 2.7 & 6.5 \\
\hline Total cover & 17.10 & $2.53 *$ & 16.64 & $4.17 *$ & 15.65 & $4.21 *$ & 14.64 & $5.28 *$ & 15.72 & $4.22 *$ & & \\
\hline Total minus clubmoss & 8.07 & $2.33 *$ & 6.51 & $3.86^{*}$ & 7.28 & $4.10^{*}$ & 5.89 & $5.01^{*}$ & 6.35 & $3.86^{*}$ & & \\
\hline
\end{tabular}

${ }^{1} \mathrm{C}=$ check

${ }^{2} \mathrm{~F}=$ furrowed.

${ }^{*}$ Means significantly different from the check $(P=0.1)$.

that this increase accounted for about $60 \%$ of the herbage production increase on the contour furrowed plots. In this study, contour furrowing increased available soil water, measured as $\mathrm{cm}-$ days, 107 and $36 \%$, respectively, on the panspot and saline-upland sites. A regression analysis of the available soil water and yield data indicated that during 1969-75, 67\% of the yield variation was explained by soil water differences. However, in 1976, only $40 \%$ of the yield variation could be accounted for by available soil water differences. This was due in part to infestations of yellow sweetclover on some of the contour-furrowed sites which, in some instances, more than doubled herbage production. We suspect that the ability of sweetclover to fix atmospheric nitrogen was the main reason for the high sweetclover production, which reemphasizes the role of $\mathrm{N}$ in limiting the productivity of these range sites.

\section{Conclusions and Application}

The results of this study show that contour furrowing is an effective tool for increasing soil water and herbage production on panspot and salineupland range sites. Species composition changes were beneficial for increased production of grazeable herbage.
Where the inherent productivity is very low, as on the saline-upland site in this study, increases in productivity up to $200 \%$ may not be economically feasible. On the panspot site, productivity levels were approaching the range of economic consideration, and treatment application decisions would have to be based on current cost-benefit ratios which are determined primarily by treatment costs, treatment longevity, and livestock values. With a furrowing machine and furrow construction such as discussed by Neff (1973) and Wight (1973), furrowing treatments should cost less than $\$ 50 /$ ha ( $\$ 20 /$ acre).

In a previous study on a similar range site, Neff (1973) estimated that furrows lost over half of their water detention capacity within 10 years and had an effective life (at least $1.3 \mathrm{~mm}$ water detention capacity) of about 25 years. The furrows in this experiment were carefully constructed with an original water detention capacity of about 40 $\mathrm{mm}$. After 10 years, the furrows were well stabilized and still had about 20 $\mathrm{mm}$ water detention capacity. Their effective life should extend well beyond 25 years. Also, as indicated by the data of Soiseth et al. (1974), the beneficial effects of contour furrowing should be autocyclic-i.e., as more water enters the soil, salinity decreases and herbage production increases, re- sulting in increased infiltration and nutrient availability which, in turn, favors increased herbage production. Thus, the beneficial effects of contour furrowing may last well beyond the actual effective life expectancy of the furrows.

The furrowed panspot site plots averaged $527 \mathrm{~kg} / \mathrm{ha}$ more herbage than did the check plots. Assuming only $50 \%$ utilization of the additional forage and $370 \mathrm{~kg}$ dry matter/AUM for summer grazing (Cook 1970), contour furrowing would increase the carrying capacity by $0.71 \mathrm{AUM} /$ ha per year. For AUM values of $\$ 3.00-\$ 6.00$, contour furrowing would be worth from $\$ 2.13$ $\$ 4.26 /$ ha $(0.86-\$ 1.72 /$ acre $)$ per year. The presence of a $\mathrm{N}$-fixing legume, yellow sweetclover, in 1976, greatly enhanced the value of contour furrowing on the $\mathrm{N}$-deficient soils. With a yield difference of $1,020 \mathrm{~kg} / \mathrm{ha}$ between check and furrowed plots; contour furrowing would have been worth from $\$ 4.14-\$ 8.28 /$ ha per year $(\$ 1.67$ $\$ 3.34$ /acre per year) in 1976 . Also of value, but difficult to give monetary values, are the beneficial effects of contour furrowing for watershed protection and wildlife needs.

\section{Literature Cited}

Barnes, O. K. 1950. Mechanical treatments on Wyoming range land. I. Range Manage. 3:198-203. 
Bennett, Hugh Hammond. 1939. Contouring. p. 434-442. In: Hugh Hammond Bennett, Soil Conservation. McGraw-Hill Book Co., Inc., New York and London.

Cook, C. Wayne. 1970. Energy budget of the range and range livestock. Colorado State Univ. Exp. Sta. Bull. TB109.

Neff, Earl L. 1973. Water storage capacity of of contour furrows in Montana. J. Range Manage. 26:298-301.
Neff, Eārl L., and J. Ross Wight. 1977. Overwinter soil water recharge and herbage production as influenced by contour furrowing on eastern Montana rangelands. J. Range Manage. 30:193-195.

Soiseth, R. J., J. R. Wight, and J. K. Aase. 1974. Improvement of panspot (solonetzic) range sites by contour furrowing. J. Range Manage. 27:107-110.

Wight, J. Ross. 1973. Range improvement practices: mechanical and fertilization. p. 111 In: Proc., The Range Beef Cow, A Symposium on Production III. Rapid City, S. Dak. Dec. 17-19.

Wight, J. Ross. 1976. Land surface modifications and their effects on range and forest watersheds. In: Proc. of the Fifth Workshop of the United States/Australia Rangelands Panel: Watershed Management on Range and Forest Lands, Utah State Univ., Logan. 